\title{
ホットプレス窒化ケイ素の鏡面研削加工
}

\author{
酒井清介・伊藤 勝 - 伊 藤正 治
}

(名古屋工業技術試験所, 462 名古屋市北区平手町 1-1)

\section{Mirror Finished Surface Grinding of Hot-Pressed Silicon Nitride}

\author{
Seisuke SAKAI, Masaru ITO and Shoji ITO \\ (Government Industrial Research Institute, Nagoya, 1-1, Hirate-cho, Kita-ku, Nagoya-shi
}

462)

\begin{abstract}
Mirror finishing of hot-pressed silicon nitride ceramics was studied by grinding using conventional abrasive wheels. In order to obtain mirror finished surface, it is necessary to grind at lower grinding pressure using a proper abrasive wheel of $I-K$ grade. In this case, rubbing without cutting results in a large amount of residual stock and mirror finished surface free from thermal cracks. Then, in this method, the finishing surface of 0.04-0.02 $\mu m R_{\max }$ was obtained for some kinds of fine ceramics.

[Received October 27, 1987 ; Accepted December 15, 1987]
\end{abstract}

Key-words: Hot-pressed silicon nitride, Mirror finished surface, Vitrified grinding wheel, Grinding mechanism, Grinding pressure, Rubbing

\section{1. 緒言}

最近の炭化ケイ素，窒化ケイ素等の焼結材料の機械的 強度の向上は著しく，その耐摩耗性，耐腐食性，耐熱性 等の特徵を生かした各種の機械構造部品への利用が期待 されている. 一方，これらの材料を構造部材として使用 するためには, 従来のセラミックス部品には見られな かった寸法, 形状精度と表面粗さが要求され, その達成 の可否が, セラミックスの適用の可否を決めることにも なる. 特に, これらのセラミックス材料を耐摩耗材料と して使用するとき，その表面加工は他の材料との摺動を 通して接触面の摩耗に大きな影響を及ぼす。このため多 くの場合鏡面加工が要求されるが，七ラミックスの鏡面 研削加工法に関する報告は少ない1).

本報告では高強度, 耐熱セラミック材料であるホット プレス窒化ケイ素焼結体のアルミナ系及び炭化ケイ素系 ビトリファイド砥石による鏡面研削加工を試み, その加 工条件について検討した.

\section{2. 実験方法}

実験には岡本平面研削盤 PSG-6BV を用い, ホット プレス窒化ケイ素焼結体の湿式トラバース研削 $(f=$ $1.2 \mathrm{~mm} / \mathrm{pass}$ ) を砥石周速 $V=1800 \mathrm{~m} / \mathrm{min}$, テーブル 速度 $V=10 \mathrm{~m} / \mathrm{min}$ で行った. 試料は幅 $15 \mathrm{~mm}$ 長さ 60 $\mathrm{mm}$ とし,これをスチール板上に接着したものをマグ ネットテーブルに固定した。使用した砥石は WA60 K 7 $\mathrm{V}$ 及び GC $60 \mathrm{~J} 7 \mathrm{~V}$ のビトリファイド砥石で, 実験に先 立つ工作物の前加工用砥石としてレジノイドボンドダイ ヤモンド碴石 SD 400 P 75 BA を使用し前加工面として ほぼ $0.8 \mu \mathrm{m} R_{\max }$ の表面粗さとした。 また, ビトリファ
イド砥石の目直しは $3 / 4 \mathrm{ct}$ の単石ダイヤモンドドレッ サーで行い, ダイヤモンド砥石の目直しは GC ステッ ク砥石をテーブル上に固定しここれを研削することによ り行った.

\section{3. 実験結果}

図 1 はダイヤモンド砥石とアルミナ砥石における設定 切り込み量に対する工作物除去量の差を示し, 1 回のク ロスフィード研削による結果である。WA 砥石による 図に示すような条件下での工作物除去量は, 設定切込み 量 $\Delta \leqq 12 \mu \mathrm{m}$ では約 $12 \%$ ，また $\Delta>12 \mu \mathrm{m}$ では約 $20 \%$ となることを示す．いずれの場合も，ダイヤモンド砥石 の約 $60 \%$ と比べて工作物除去量は著しく少なく, 設定 切り込み量との差は砥石減耗と砥石軸等の弾性変形によ る逃げと考えられる。また，図 2 はWA 砥石での設定 総切り込み量に対する砥石減耗量亡工作物除去量を測定 し, 切り残し量を求めたものである. 総切り込み量で $20 \mu \mathrm{m}$ 程度までは砥石切り込み量の大部分は切残し量と

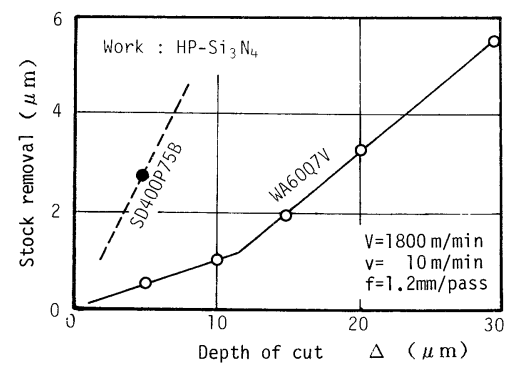

Fig. 1. Effect of depth of cut on stock removal for diamond and vitrified alumina wheels. 


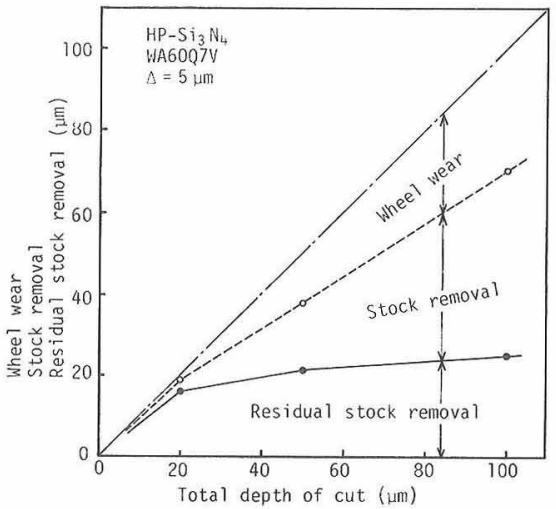

Fig. 2. Effect of total depth of cut on wheel wear, stock removal and residual stock removal.

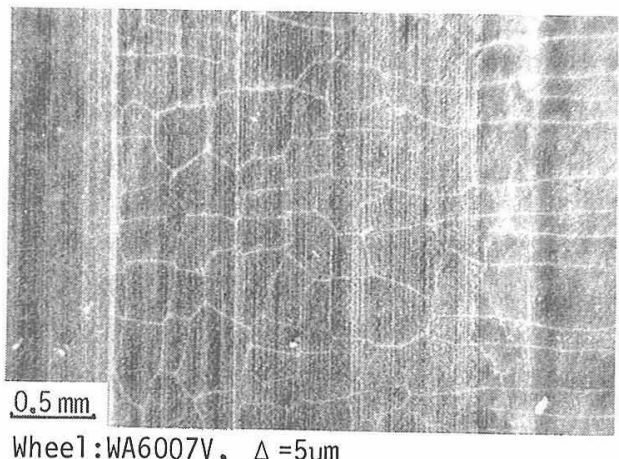

Fig. 3. Thermal cracks developed on surface ground by vitrified alumina wheel.

なるのに対し，これ以上の切込みでは工作物の除去が進 み，同時に砥石減耗も増大することを示している。すな わち, WA 砥石による研削でも, 総切り込み量の増加 に伴い加工压が増加すると研削機構が変化することが分 かる2). 低加工圧下では cutting 作用はほとんどなく rubbing 作用が主体で前加工面がミクロに除去されるの に対し，高加工圧下ではチッピングによる工作物除去も 行われると考兄られる。なお，図3は硬い結合度の砥石 を使用した場合の研削加工面の研削熱に起因するクラッ クを示す．WA砥石による研削で砥石の適度の破砕, 脱落が伴わないとき, 摩耗した切れ刃との摩擦により過 大な研削熱が発生し，これに起因する熱衝撃によって時 としてこのようなクラックが生じる.これらのクラック の深さは，加工面の除去による観察加ら約 $35 \mu \mathrm{m}$ にま で達する. したがって, 使用砥石は破砕と脱落が適度に 生じる結合度を持つことが必要であり, 結合度 $\mathrm{I}$ ～K の 砥石では上記のようなクラックの発生は全く見られな い.ただし，砥石減耗は更に著しく研削比で 0.02 程度 となる。

図 4 はダイヤモンド砥石（SD 400 P 75）を用い 0.8 $\mu \mathrm{m} R_{\max }$ に前加工した窒化ケイ素焼結体をアルミナ砥

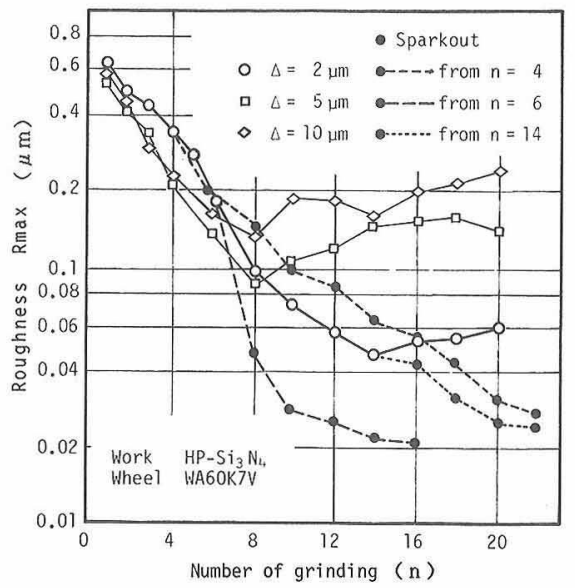

Fig. 4. Change of surface roughness ground by vitrified alumina wheel.

石 (WA $60 \mathrm{~K} 7 \mathrm{~V}$ ) により砥石切込み量 $\Delta=2,5,10 \mu \mathrm{m}$ で研削加工した場合の研削回数に対する加工面粗さの変 化を示す．いずれも研削初期は研削回数の増加に伴い加 工面粗さは向上するが，その後は碰石切り込みに対して 加工面の悪化が見られる.これは，図 2 からも分かるよ うに研削初期で切残し量がまだ増加の段階は rubbing 作 用が主体で, 前加工のダイヤモンド砥石による研削条痕 が除去される過程であり, 加工面粗さは向上する.しか し, 最小粗さを示す研削回数以後の加工面は, 過大な切 残し量によって砥石と加工物の接触面圧が増加する.こ のため加工面には微小なチッピングの発生を見るととも に工作物除去が始まり, 加工面も悪化する。したがって, この加工法で良好な加工面を得るためには加工圧を適正 な值に制御する必要がありこのためにスパークアウト が重要な意味を持つ. 図 4 に砥石切込み量 $\Delta=2 \mu \mathrm{m} の$ 場合について, 研削回数 $n=4,6,14$ 回以後をスパーク アウトとしたときの加工面粗さの変化を点線で示す。ス

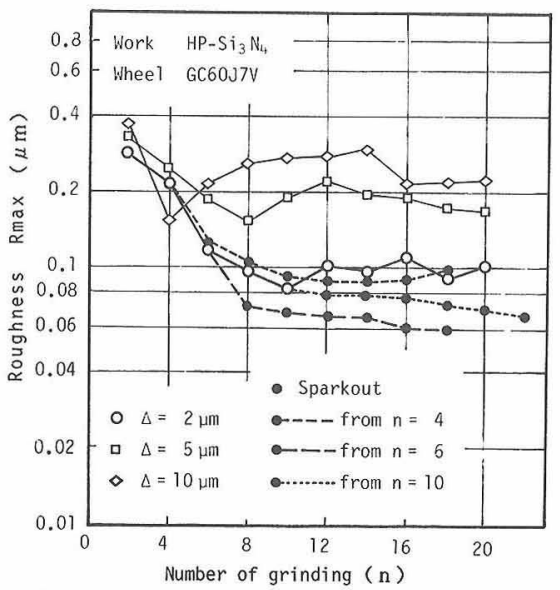

Fig. 5. Change of surface roughness ground by vitrified silicon carbide wheel. 
パークアウトに移る時期によって，その後の粗さ変化に かなりの差が認められ, $n=6$ 回からのスパークアウト では研削回数 10 回で $0.02 \mu \mathrm{m} R_{\max }$ の粗さが得られる. また, GC 砥石を用いた場合の加工面粗さの変化は, 図 5 に示すようにWA 砥石の場合と同様の傾向にあるが, 最終加工面粗さは前者に比べてかなり悪い（こ0.06 $\mu \mathrm{m}$ $\left.R_{\text {max }}\right)$. 被研削材である窒化ケイ素より硬度の高い炭化 ケイ素砥粒による研削加工ではWA 砥粒によって得ら れるほどの仕上げ面は得られないことを示す.

このような WA ビトリファイド砥石による鏡面研削 加工は, 対象材料がホットプレス窒化ケイ素にかぎらず, 他の高硬度で緻密な構造用セラミックスに対しても適用

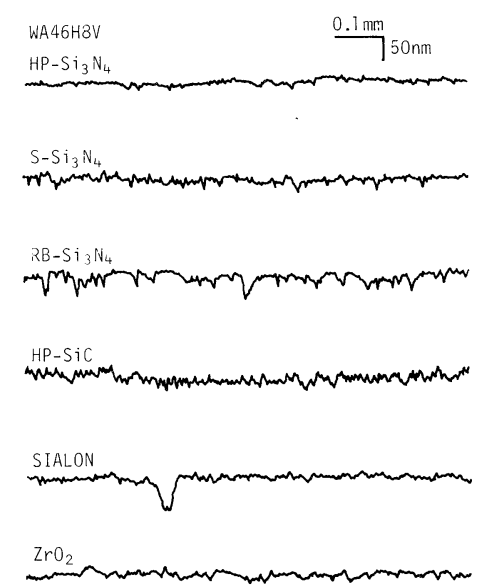

Fig.6. Surface profiles ground by vitrified alumina wheel.
できる可能性がある.図 6 は他の材料を対象とした場合 の加工面のプロフィールを示す．材料により同一条件下 で得られる加工面粗さに差が認められ, ある程度の気孔 を含む常圧焼結材, 反応焼結材に比べ緻密な材料ではよ り良好な加工面が得られる. しかし, いずれの場合も $0.04 \sim 0.02 \mu \mathrm{m} R_{\text {max }}$ 程度の仕上げ面が比較的容易に得 られる.

\section{4. 結 論}

ホットプレス窒化ケイ素焼結体の鏡面研削加工に WA 及び GC ビトリファイド研削砥石を適用すること を試み, 二,三の実験を行った結果次のような結論を得 た。

（1）被研削材である窒化ケイ素とほとんど硬度が変 わらないWA ビトリファイド砥石による研削は，加工 圧の増加に伴って研削機構が変化し, 低加工圧下では rubbing 作用が主体となり鏡面加工が可能である。この 結果, WA $60 \mathrm{~K} 7 \mathrm{~V}$ の砥石で $0.02 \mu \mathrm{m} R_{\max }$ の仕上面が 得られる. また, 高加工圧下では被加工物のチッピング により工作物除去も進むが加工面は悪化する.

（2）この加工法は他の緻密な数種類のセラミックス 焼結体に対しても適用可能であり，いずれも0.04 $0.02 \mu \mathrm{m} R_{\max }$ の仕上げ面が得られた.

$$
\text { 文献 }
$$

1）杉田忠彰, “セラミックスの機械加工”, 養賢堂 (1985) pp. 140-44.

2）富森 紘, 砥粒加工研究会会報, 28, 1, 1-9 (1984). 